\title{
Hiperkolesterolemia Familiarra: patofisiologia, diagnostikoa eta tratamendua
} Familial Hypercholesterolemia: physiopathology, diagnosis and treatment

\author{
Unai Galicia-Garcia ${ }^{1}$, Jone Amuategi ${ }^{2}$, Shifa Jebari ${ }^{2}$, Asier Larrea-Sebal ${ }^{1}$, Kepa B. Uribe ${ }^{3}$, \\ Helena Ostolaza ${ }^{2}$, Cesar Martin ${ }^{2}$, Asier Benito-Vicente ${ }^{2^{*}}$ \\ ${ }^{1}$ Fundación Biofisika Bizkaia(FBB), Biokimika eta Biologia Molekularra Saila (UPV/EHU) \\ ${ }^{2}$ Biofisika Institutua (CSIC/UPV), Biokimika eta Biologia Molekularra Saila (UPV/EHU) \\ ${ }^{3}$ Center for Cooperative Research in Biomaterials (CIC biomaGUNE)
}

asierbenitovicente@gmail.com

\section{Laburpena}

Gaixotasun kardiobaskularra (CVD) mundu-mailan heriotza gehien eragiten duen gaixotasuna da eta haren garapena bizimodu ez osasuntsu bat eramatearekin erlazionatzen da. Hala ere, banako batzuek faktore genetikoak direla-eta gaixotasuna pairatzeko arrisku handiagoa dute. Hiperkolesterolemia Familiarra (HF), gaixotasun autosomiko gainartzailea da, eta bereziki, 3 gene ezberdinetan gertatzen diren mutazioen ondorio da. Gaixotasun honek eragindako LDL kolesterol (LDL-C) maila altuek CVD pairatzeko arriskua nabarmenki handitzen dute. Hori dela-eta, lan honetan HFa sortzen duten faktore genetikoei, gaixotasunaren diagnosiari, tratamenduari eta HFaren eta CVDaren arteko erlazioari buruzko errebisio bibliografikoa egin da.

Gako-hitzak: Hiperkolesterolemia Familiarra, PCSK9, LDLR, APOB100, estatinak, CVD

\section{Abstract}

Cardiovascular disease (CVD) is the main cause of mortality worldwide, and is heavily related to diet and sedentary lifestyle. However, it can also be developed due to genetic factors. Familial Hypercholesterolemia $(F H)$ is a common inherited autosomic disease mainly related to mutations in 3 different genes. $F H$ is associated with high plasma $L D L$ cholesterol ( $L D L-C)$ levels that increase the risk of suffering from CVD. This review aims to summarize the current knowledge on FH related genetic factors, disease diagnosis, treatment and the involvement of FH in the development of CVD.

Keywords: Familial Hypercholesterolemia, PCSK9, LDLR, APOB100, statins, CVD

Bidalia: 2020ko martxoaren 30ean

Onartua: 2020ko maiatzaren 25ean

http://doi.org/10.26876/osagaiz.1.2020.299

\section{Sarrera}

Gaixotasun kardiobaskularrak (ingelesez Cardiovascular diasease edo CVD) mundu-mailan 17,9 milioi heriotza eragiten ditu urtero, eta gaur egun, heriotza-tasarik handiena duen gaixotasuna da. Hainbat faktorek emendatzen dute CVDa pairatzeko arriskua, baina haien artean LDL-kolesterol (ingelesez Low-density Lipoprotein-Cholesterol edo LDL-C) maila bereziki garrantzitsua da (1). Ondorioz, CVD goiztiar askoren kasuan pazienteek hiperkosterolemia familiarra (HF) daukate. 
HFa gaixotasun autosomiko gainartzaile arruntenetarikoa da eta odol-plasman LDL-Caren kontzentrazio altuen agerpena dauka ezaugarritzat. Tratatu ezean, denbora luzez LDL-C maila handien eraginpean egoteak ateroma plakaren garapena eragin dezake eta, ondorioz, CVDaren agerpen goiztiarra eragin dezake. Horrez gain, LDL-Caren maila handia duten HF gaixoek tendoixantomak eta betazal-xantelasma nabarmenak izan ditzakete. Bestetik, HFan ehun konektiboaren eta askotariko zelulen metaketa gertatzen da arterien barrualdeko geruzan (2). Urteetan zehar, heterozigosian agertzen den HFaren (HeHF) maiztasuna 1:500 inguruan zegoela uste izan da. Hori, ordea, ez da guztiz zuzena eta egungo ikerketek maiztasuna 1:200 eta 1:300 tartean finkatu dute; alabaina, erabilitako aldagaiaren (mutazio bakunak, LDL-Caren maila, pazientearen kalifikazio klinikoa edota aldagai guztiak batera) eta ikertutako populazioaren arabera balio horiek alda daitezke. Homozigosian agertzen den HFaren kasuan (HoHF), prebalentzia 1:1.000.000 inguruan dagoela uste da, nahiz eta ikertutako populazioaren arabera 1:300.000ko prebalentziara iritsi daitekeen (3).

\section{Hiperkolesterolemia Familiarra eta genetika}

HFa zelulek kolesterolaren barneraketa-mekanismoan duten akatsen ondorio da. HFa pairatzea eragiten duten mutazioen artean arruntenak LDLaren hartzaile (LDLR) (mutazioen \% 80-85), ApolipoproteinaB-100 (APOB100) (\% 5-10), Proproteina Konbertasa Subtilisina/Kexina familiako bederatzigarren kide (PCSK9) (\% 2) edo LDLaren hartzailearen proteina egokitzaile (LDLRAP1) (<\% 1) geneetan ematen dira (4). Horiez gain, nahiz eta prebalentzia oso txikia izan, Apolipoproteina E (APOE), seinaleak itzultzen dituzten egokitzaileen familiako lehenengo kide (STAP1), lisosomako lipasa azido (LIPA) eta G5/8 azpi-familiako kasete ATP lotzaile (ABCG5/8) geneetan aurkeztu daitezkeen zenbait mutaziok ere HFaren antzeko fenotipoa sor dezakete $(5,6)$.

\subsection{LDLR}

LDLRan, HF kasu gehienen erantzulea den genean, dagoeneko 3.000 aldaera baino gehiago deskribatu dira (Clin_Var database, 2020). LDLR plasmako LDL partikulak lotu eta barneratzeaz arduratzen da, eta funtzionamenduan akatsak izanez gero, LDL-C igoarazten du plasman. LDLR proteina erretikulu endoplasmatikoan sintetizatzen eta mintz plasmatikora garraiatzen da. Bertan, LDLaren ApoB100 proteina estrukturala lotzen du eta klatrina menpeko endozitosi bidez barneratzen du. LDL barneraketan, endosomak azidifikatzen dira LDLR-APOB100 arteko afinitatea murriztuz eta horien arteko lotura ahulduz. Horri esker, LDL partikulak endosomako lumenera askatzen dira eta ondoren lisosomara bideratzen dira; LDLRa, berriz, mintz plasmatikora bueltatzen da birziklapenprozesu bati esker (1A eta 1B irudiak). Prozesu horretan edonolako akatsik gertatuz gero, HFa garatzen da (7).

Deskribatutako LDLR aldaera patogenikoen artean luzera handiko DNA sekuentzien bikoizketak (ingelesez Copy Number Variation edo CNV), nukleotidoen txertaketak eta delezioak, moztitsasketaguneetako mutazioak edo nukleotido-ordezkapenak aurki daitezke. Nukleotidoen txertaketen eta delezioen garrantzia azpimarratu beharra dago, nukleotido-ordezkapenekin alderatuz ondorio nabarmenak sortzen dituztelako (7).

LDLRaren mutazioak 5 klase ezberdinetan sailka daitezke, LDLR bidezidorra zein puntutan kaltetzen duten arabera (1C Irudia). Horrela, proteinaren sintesia oztopatuz gero, lehenengo klaseko mutazio gisa sailkatzen dira; mutazioek proteina erretikuluan atxikita geratzea eragiten badute, bigarren klasean sailkatzen dira; hirugarren klaseko mutazioek LDLR eta LDL arteko lotura akastuna eragiten dute; laugarren klaseko mutazioek LDLR-LDL konplexuaren barneraketa oztopatzen dute, eta bosgarren klasekoek LDLRaren birziklapen eraginkorra galarazten dute (8). 


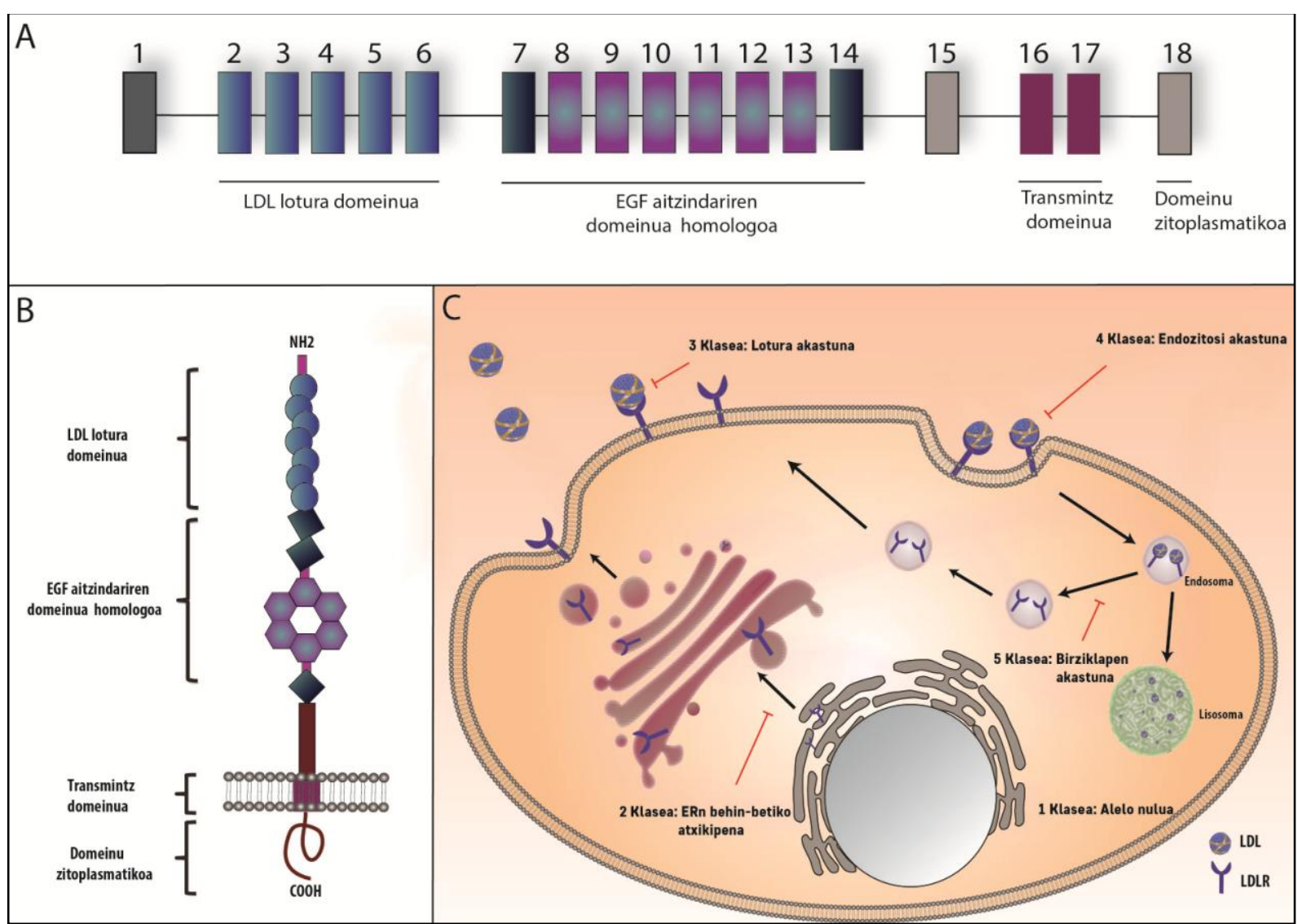

\section{1. irudia. LDLR eta bere bidezidorra.}

1A) LDLRa 18 exoi ezberdinetan kodetutako genea da; 1B) LDLRaren domeinu ezberdinen irudikapen eskematikoa; 1C) LDLRa erretikulu endoplasmatikoan sintetizatzen da. Ondoren, Golgi aparatuan eraldatzen da eta, azkenik, zelula-mintzera garraiatzen da. Zelula-mintzean LDLRak LDL partikulen ApoB100 lipoproteina lotzen du eta horrekin batera barneratzen da klatrina bidezko endozitosi-prozesu baten bidez. Endozitosi-prozesuan pHa jaisten da, eta horrek LDLR-LDL arteko loturak ahulduz bi proteinak banatu egiten ditu. Bukatzeko, LDLa lisosomara bideratzen da eta LDLRa, berriz, birziklapen-prozesu baten bitartez mintzera bueltatzen da.

\subsection{APOB100}

APOB100 genean gertatzen diren mutazioak HFa pairatzeko bigarren arrazoi nagusia dira eta LDL eta LDLR arteko lotura oztopatzen dute. ApoB100a, 4.536 aminoazidoz osatutako proteina monomerikoa da. Alde batetik, funtzio estrukturala betetzen du, LDL partikulak inguratzen eta egonkortzen baititu, eta, bestetik, LDLRari lotzeko gaitasuna dauka (9). Hortaz, odol-plasman hidrofobikoak diren lipidoak garraiatzeko ezinbesteko proteina da. APOB100ean gertatzen diren mutazio patogenikoak, loturadomeinuari dagozkion eta oso kontserbatuta dauden, 26. eta 29. exoietan deskribatu ziren lehenbiziko aldiz. Gaur egun, deskribatutako APOB100 geneko mutazio gehienak exoi horietan dauden arren, horietatik kanpo dauden zenbait mutazio patogeniko ere deskribatu dira. Horrek LDLR-LDL interakzio-gune klasikoetatik kanpo dauden sekuentzien analisiaren garrantzia azpimarratzen du. Mutazio hauek sortzen duten fenotipoa APOB akastun familiarra (AAF) izenarekin ere ezagutzen da, eta gehienetan, ez da LDLR mutazioek sortzen duten fenotipoa bezain kaltegarria izaten (10).

\subsection{PCSK9}

PCSK9 genearen aldaerak mende honen hasieran hasi ziren deskribatzen, PCSK9 eta HFaren arteko erlazioa lehenbiziko aldiz karakterizatu zenean (11). PCSK9a hiru domeinuz osatutako proproteina konbertasa bat da: prodomeinua (31-152 aminoazidoak), domeinu katalitikoa (153-449 
aminoazidoak) eta C-muturreko domeinua (CTD) (449-692 aminoazidoak) dituena (2A irudia). Proteina erretikulu endoplasmatikora iristen denean, 152. eta 153. aminoazidoen artean automozketa bat gertatzen da. Horrela, 14 kDa dituen peptido bat eta $60 \mathrm{kDa}$ dituen proteina heldu bat sortzen dira. Aipatutako peptidoa proteinari atxikita geratzen da 152-226 aminoazidoen artean, 75 kDa-ko proteina bat sortuz. Atxikidura horrek proteinaren gune aktiboa estaltzen du proteinaren konbertasa-funtzioa inaktibatuz (12).

PCSK9ak LDLaren hartzailea lotu dezake haren degradazioa bultzatuz(13). Horren arabera, PCSK9an gertatzen diren aldaerak bi motatakoak izan daitezke: funtzio areagotzaileak (ingelesez Gain-ofFunction edo GOF) edo funtzio galtzaileak (ingelesez Loss-of-Function edo LOF). GOF aldaerak HF kasuekin erlazionatuta daude, zelularen mintzeko LDLR kopurua, eta, ondorioz, odol-plasmako LDL partikulak lotu ditzakeen hartzailea, murrizten dutelako kanpo- (LDLRekiko afinitate gehiago) edo barne-mekanismoen (LDLRaren mintz-garraioa oztopatu) bidez. 2019. urtera arte 30 GOF mutazio deskribatu dira, gehienak nukleotido-ordezkapenaren ondorio dira, eta PCSK9aren hiru domeinuetan zehar banatuta daude. Horien artean transkripzioa areagotzen duten, automozketa-prozesu ezberdina jasaten duten edo LDLRarekiko afinitate handiagoa duten PCSK9 aldaerak deskribatu dira (2B irudia). LOF mutazioen kasuan, aldiz, gutxi batzuk deskribatu dira orain arte. Horiek LDL-Caren kontzentrazio baxua eragin ohi dute, LDLR gehiago baitago eskuragarri, eta horrek CVDaren aurkako babesa ematen du (14).

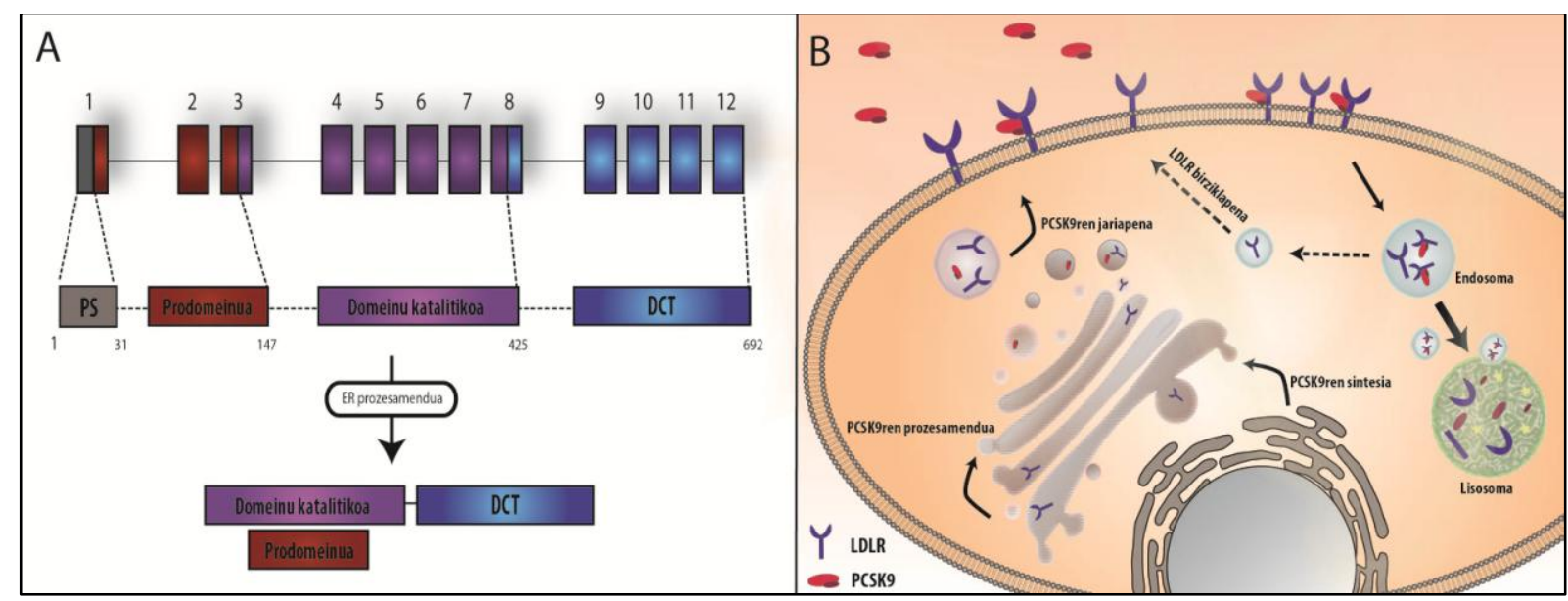

2. irudia. PCSK9aren prozesamendua eta funtzioa.

2A) PCSK9aren sintesiaren eta prozesamenduaren irudikapen grafikoa. 2B) PCSK9 aldaeraren funtzio areagotzailearen zelulaz kanpoko funtzioaren irudikapena. PCSK9 aldaera areagotzaile batzuek LDLRarekiko kanpo-afinitate handiagoa daukate eta, ondorioz, endozitosi-prozesuan, pHaren jaitsiera gertatzean, LDLR-PCSK9 konplexua ez da askatzen. Horrek, LDLRaren degradazioa bultzatzen du haren birziklapena ekidinez.

\subsection{LDLRAP1}

LDLRAP1 proteinak LDLR-LDL konplexuaren barneraketan parte hartzen du, LDLRaren domeinu zitoplasmatikoaren eta klatrina molekulen arteko bitartekari moduan. LDLRAP1aren mutazio ezfuntzionalek, bi aleloetan aldi berean gertatuz gero, LDL partikulen klatrina bidezko barneraketa oztopatzen dute, plasmako LDL maila emendatuz (15).

\section{Bigarren mailako Hiperkolesterolemia Familiarra}

LDL-Caren maila handiak LDL partikulen katabolismoan parte hartzen duten gene akastunekin lotuta egon ohi dira. Zenbait kasutan, ostera, LDL-Caren maila beste gaixotasun batzuen edota inguruko faktoreen ondorioz ere igo daiteke. Esaterako, ABCG5/8 gene akastunek sitosterolemia sortzen dute. Kasu horietan, HFan gertatzen den moduan, pazienteek LDL-Caren maila handia eta arrisku kardiobaskular handia ohi dituzte. Hala ere, gaixotasun hau ez dago LDLaren metabolismoari lotuta, 
landare-esterol pilaketari baizik. Horregatik, landare-esterol horien xurgapena blokeatzeko era askotariko tratamenduei jarraitu behar diete (16).

Sitosterolemiaz gain, beste gaixotasun batzuek ere LDL-Caren maila igo dezakete LDLaren katabolismoan inolako eraginik izan gabe: sindrome nefrotikoak, gibelaren funtzio-galerak, kolestasiak edo hipotiroidismoak, esaterako (17-19).

\section{Hiperkolesterolemia Familiarra eta gaixotasun kardiobaskularra}

HFak eragindako kolesterol-maila handiek CVDaren maiztasuna handitzen dute, batez ere aterosklerosiaren garapen goiztiarra eragiten baitute $(20,21)$. Aterosklerosia CVDaren eragilerik ohikoena da, eta normalean, arterien diametroa txikitzen du, eta bihotzekoak eta hainbat hodietako gaitzak pairatzeko arriskua handitzen du. Odolean pilatzen diren LDLek eta VLDLek (ingelesez VeryLow Density Lipoprotein) pareta endoteliala gurutzatzen dute eta endotelioaren azpiko geruza barrukoenean metatzen eta oxidatzen dira. Metaketa horiek endotelioa ahulduta dagoen lekuetan bereziki nabariak dira, arterien bihurguneetan eta adarkaduretan, adibidez. Bertan, odolak daukan fluxu zurrunbilotsua dela-eta, hodien hormek estres mekaniko handiagoa jasaten dute (22). Gainera, endotelioko zelulek jasaten duten estres mekanikoaren ondorioz, molekula kimiotaxikoak eta adhesiorako molekulak sintetizatzen eta kanporatzen dira, monozitoen migrazioa eta endotelioan zeharreko garraioa sustatuz (23). Behin intima barruan, monozitoak makrofago heldu bilakatzen dira eta bertan dauden oxidatutako lipoproteinak barneratzen dituzte, erregulaziorik gabeko scavenger hartzaileen (SR) bitartez (24). Kontrolik gabeko kolesterolaren barneraketak horrelako metaketa handiak eragiten ditu intimako makrofagoetan, Makrofago horiek zelula apartsu bihurtuz. Denborarekin, zelula apartsuak ugaritzeak makrofago berriak erakartzen ditu eta intima azpiko geruzan dauden muskulu zelulen (ingelesez Smooth Vascular Muscle Cells edo SVMC) migrazioa eragiten du. Horrela, zelulak pilatzen dira (aterosklerosi-plaka) arterien diametroa murriztuz (3. irudia). Aterosklerosiaren azken faseetan intima azpian pilatutako zelulek metaloproteinasa ezberdinak sintetizatzen eta kanporatzen dituzte (25). Horiek aterosklerosi plaka desegonkortu eta apurtu dezakete, bihotzekoak edo gaixotasun baskularrak izateko arriskua areagotuz.

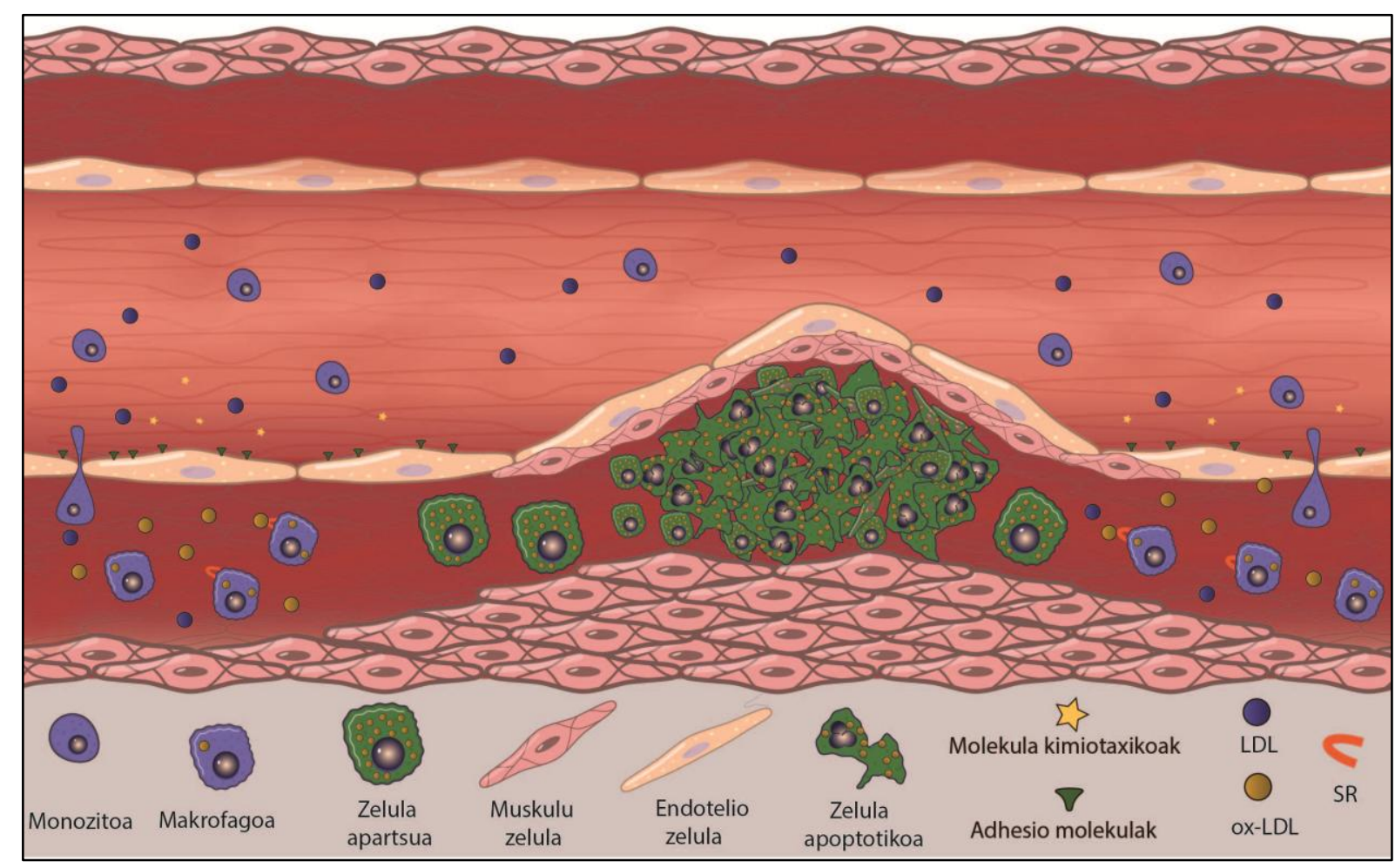

3. irudia. Ateroma-plakaren garapena. 


\section{Hiperkolesterolemia Familiarraren diagnosia}

HFaren diagnosi egokia eta fidagarria egiteko zenbait gida daude eskuragarri. Haien artean, Simon Broome Register Group (SBRG) (26), Male Early Diagnosis to Prevent Death eta Duch Lipid Clinic Network (DLCN) (4) dira erabilienak. Gida gehienek antzeko irizpideak erabiltzen dituzte HFa diagnostikatzeko orduan, haien arteko ezberdintasun nabarmenena irizpide bakoitzari emandako garrantzia izanik. Irizpide horien artean sintoma fisikoak (tendoi-xantomak eta korneako arkua), odolplasmako kolesterol-maila, HF aurrekari familiarrak, pazientearen historia klinikoa edo/eta DNA analisiak agertzen dira.

Irizpideen artean, DNA analisia dudagabeko diagnosirako parametrorik fidagarrienetarikoa da, horrekin HFa sor dezaketen mutazioak erraz detektatu baitaitezke. Hala ere, test genetikoen bidez diagnosi zehatz bat lortzeko informazio osagarria ezinbestekoa da (27). Analisi funtzionalek eta kosegregazio-analisiek esaterako, test genetikoek eskaintzen duten informazioa osotzen dute, horrela, HFaren diagnosi fidagarri bat ahalbidetuz. Gainera, kosegregazio-analisiak ez bezala, analisi funtzionalak ikerketa laborategi batean erraz egin daitezke, ez daukate pazienteekiko inolako menpekotasunik eta $\mathrm{HFa}$ sortzen duten mutazioen mekanismoa ikertzeko aukera ematen dute $(28,29)$.

Zenbait gaixok, HFarekin bateragarriak diren parametro klinikoak izan arren, analisi genetikoan emaitza negatiboak eduki ditzakete. Horren atzean ezkutatzen diren arrazoiak bi izan litezke. Batetik, HFari lotutako generen batean, gehienetan APOB100ean, detektatu izan ez den mutazioren bat egotea (10), eta bestetik, antzeko ezaugarri klinikoak dituen gaixotasun baten ondorio izatea, esaterako: hiperkolesterolemia poligenikoa, disbetalipoproteinemia edo hiperkolesterolemia familiar konbinatua (30). Aipaturiko azken bi gaitzetan, ordea, HFak eragindako ezaugarri klinikoez gain (LDL$\mathrm{C}$ altuak, tendoi-xantomak eta gaixotasun kardiobaskularraren aurrekariak), trigilizeridoen maila handia izan ohi dute bereizgarri gisa (31).

\section{LDL-Ca murrizteko terapiak eta haien bilakaera}

Kolesterolaren maila handia izateak ez dauka sintoma zuzenik eta, horregatik, askok ez dakite HFa dutenik. CVDa pairatzeko aukerak, atalase-maila batetik gora (kolesterol-maila totala $>200 \mathrm{mg} / \mathrm{dL}$ eta LDL-C maila $>100 \mathrm{mg} / \mathrm{dL}$ ) asko handitzen dira. Hortaz, HFak eragindako sintomen tratamendu goiztiarra erabakigarria da. Gaur egun, estatinak dira farmakorik erabilienak. Hala ere, gaur arte, beste hainbat farmako zein farmako-konbinazio erabili dira (4. irudia). HoHF eta HeHF kasu larri batzuetan adibidez, estatinetan oinarritutako tratamendua kolesterola murrizteko beste farmako batzuekin batera erabili behar da emaitza egokiak lortzeko (32).

\subsection{Estatinak}

Estatinak odoleko lipido-maila murrizteko mundu-mailan gehien agindutako medikamentuak dira eta, kolesterol-mailak jaisteaz gain, kausa kardiobaskularrengatiko hilkortasunaren jaitsiera frogatu duten bakarrak dira. HMG-KoA (3-hidroxi-3-metilglutaril-koentzima A) erreduktasaren eta mebalonatoaren bidezidorrean ekoiztutako metabolitoen sorrera inhibitzen dute, biak gibeleko kolesterol-sintesian parte hartzen duten konposatuak izanik. Horri esker, zelula barneko kolesterolekoizpena asko murrizten da, LDLRaren adierazpena eta "aktibitatea" (mintzean dauden LDLR molekulen kopuruaren igoera bezala ulertuta) handitzen da, eta, ondorioz, LDL partikula gehiago barneratu daitezke eta odoleko LDL-C maila jaitsi. Prozesu hori bereziki garrantzitsua da hepatozito edo gibeleko zeluletan. Beraz, estatinek plasmako LDL eta VLDLen zeharkako desagerpena bultzatzen dute, gibelean eta ehun periferikoetan LDLRen adierazpena handituz (33). Gainera, lipidoen beste parametro batzuetan ere eragin onuragarria daukate, besteak beste, HDL (ingelesez High-density Lipoprotein) maila handitzen edota triglizeridoena gutxitzen baitute. Estatinak Akira Endok deskribatu zituen 70eko hamarkadan, baina ez ziren salmentan jarri 1986 arte. Orduan merkaturatu zen 
lovastatina, HMG-CoA erreduktasaren inhibitzailea. Gaur egun, gehien erabiltzen diren estatinak lovastatina, fluvastatina, sinvastatina, atorvastatina eta rosuvastatina dira. Beraien artean eraginkorrenak, azken biak, HoHF gaixoetan ere LDL maila murrizteko gai dira, ziur aski gibeleko LDLC ekoizpena murrizten dutelako (34).

Estatinak bi taldetan banatu daitezke: jatorri naturala dutenak edo horietatik eratorriak izan direnak (lovastatina, simvastatina, mevastatina eta pravastatina); eta jatorri sintetikoa dutenak (atorvastatina, fluvastatina, rosuvastatina, cerivastatina eta pitavastatina). Azken horietan, fluorofenil talde batek lehenengo motakoen butiril taldea ordezkatzen du gehienetan. Estatinen izaera hidrofilikoak ere beraien hepato-hautakortasuna zehazten du eta, hortaz, beraien jatorriaz gain duten hidrofilikotasunaren arabera ere sailkatu daitezke, hidrofilikoak (rosuvastatina eta pravastatina) edo hidrofoboak (atorvastatina, simvastatina, fluvastatina, lovastatina eta cerivastatina). $\mathrm{Bi}$ motatako estatinak selektiboki barneratzen dira hepatozitoetan; ehun periferikoetan, berriz, bi era ezberdinetan barneratzen dira. Estatina hidrofobikoek eragin handiagoa izaten dute ehun ez-hepatikoetan, era pasiboan barneratu daitezkeelako mintzean zehar. Estatina hidrofilikoak, aldiz, gibelarekiko espezifikoagoak dira, garraio aktibo bidez barneratzen direlako hepatozitoetan (35).

Nahiz eta estatinen eraginkortasuna eta segurtasuna frogatuta egon, gaixo batzuetan denboraldi luzeko eta dosi handiko tratamenduen ondorioz eragin kaltegarriak deskribatu dira. Ohikoenak estatina lipofilikoei lotutako muskuluetako sintomak dira, mina edo ahultasuna, adibidez. Horregatik, uretan disolbagarriak diren estatinak (pravastatina, rosuvastatina) hobesten dira kasu horietan. Estatinek bigarren motako mellitus diabetesean (DMII) daukaten eragina ere aztertzen ari dira, dosi handiko tratamenduak DMIlaren garapenarekin lotu baitira (36). Estatina lipofilikoek, hidrofilikoekin alderatuz, metabolismoan eragin kaltegarriak sortu ditzakete, intsulinaren jariapen desegokia edo intsulinarekiko erresistentziaren garapena, besteak beste. Hala ere, arrisku kardiobaskular handia eta diabetesa duten pazienteetan estatinen erabilera gomendatzen da onura/arrisku ratioa handia delaeta (36).

\subsection{Ezetimibe}

Ezetimibe kolesterolaren hesteko xurgapena era selektiboan inhibitzen duen molekula da. Bigarren mailako tratamentua da, estatinak hartu ezin direnean edo estatinekin nahikoa ez denean haiei gehituz erabiltzen da. NPC1L1 hartzailea inhibitzen du, bai enterozitoen lumenean bai interfase hepatobiliarrean. Horrek, kolesterolaren xurgapena modu eraginkorrean inhibitzen du, baina triglizerido eta gantzetan disolbagarriak diren bitaminen xurgapenean, berriz, ez du eraginik. Hesteetan kolesterolaren xurgapena inhibitzeak kolesterol-behazunen birxurgapena inhibitzeaz gain, kilomikroi gutxiago sortzea eta jariatzea eragiten du. Horrek, hepatozitoetako kolesterol-gordekinak xahutzea dakar. Gibelean kolesterol gutxiago izateak LDLR adierazpena bultzatzen eta VLDL sintesia murrizten du odol-plasmako LDL-C kontzentrazioa murriztuz (37).

\subsection{Giza jatorriko anti-PCSK9 antigorputz monoklonalak}

Giza jatorriko anti-PCSK9 antigorputz monoklonalak, arrisku altuko gaixoetan bereziki, LDL-Caren maila jaisteko eta CVDaren arriskua murrizteko gai direla frogatu da. Beraien erabilpena gomendatzen da estatinekin eta ezetimibekin tratatutako gaixoetan kolesterol-maila behar beste murrizten ez denean. Gaur-gaurkoz, bi antigorputz ezberdin erabiltzen dira: alirocumab eta evolocumab. Biak giza IgG azpitaldekoak dira eta odolean dagoen PCSK9ari batzen zaizkio, horrek LDLRarekin duen lotura-gunea blokeatuz. Ondorioz, LDLR gutxiago birziklatuko da, mintzean LDLaren hartzaile gehiago mantenduz eta LDL partikula gehiago barneratuz. Nahiz eta anti-PCSK9 antigorputzek albo-kalte gutxi eduki eta oso eraginkorrak izan, momentuz, terapiaren kostu handiak, luzera begirako segurtasunari buruzko datu gutxi izateak eta periodikoki injektatu beharrak haren erabilpena zabaltzea ekidin dute (38). 


\subsection{Niazina}

Niazina, B3 bitamina edo azido nikotiniko izenekin ere ezagutzen dena, HFaren tratamendurako erabili zen lehenengo farmako lipido-eraldatzailea izan zen. Niazinak gantz azido askeen (ingelesez Free Fatty Acid edo FFA) gantz-ehunetik kanporako garraioa murrizten du, bertako proteina lipasa sistema inhibituz. Hortaz, gibeleko FFAen erabilgarritasuna mugatzean, kolesterolaren eta triglizeridoen ekoizpena murrizten du. Niazinaren ohiko albo-kalteak basodilatazioarekin eta entzima hepatikoen mailaren gehiegizko igoerarekin erlazionatzen dira (39). Gaur egun, niazina ez da gomendatzen hiperlipemiaren tratamenduan, kasu bakar batzuetan izan ezik (hipertriglizeridemiamaila altuak $>500 \mathrm{mg} / \mathrm{dL}$ izanik baldin eta beste tratamendu batzuekin ez badira maila gomendagarriak lortzen edota lehen mailako tratamenduen intolerantzia-kasuetan).

\subsection{Behazun-azidoen bahitzaileak}

Azido biliarraren bahitzaileak 1975. urtean merkaturatu ziren. Molekula haoriek azido biliarkolesterol mizelekin elkartzean konplexu disolbaezin bat eratzen dute. Horrela, hesteetako zeluletan, enterozitoetan, barneraketa ekiditen eta kolesterolaren kanporaketa sustatzen dute. Enterozitoek kolesterol gutxiago barneratzen dutenez, haien eta gibelaren arteko kolesterol-garraioa partzialki inhibituta dago. Ondorioz, gibelera iristen den kolesterol-maila txikiagoa da. Hori dela-eta, LDL eta VLDL jariaketa murriztu egiten da, lipoproteina horien odoleko maila jaitsiz. CVDak murrizteko gai direla frogatu da $(40,41)$; horiek, ordea, askotan ez dira ondo jasaten. Gaur egun hiperkolesterolemia familiarrean ez dira ez lehenengo, ez bigarren eta ez hirugarren aukerako tratamenduak. Beste tratamenduak eraginkorrak ez direnean edo intolerantziak daudenean erabil daitezke. Izan ere, gantzetan disolbagarriak diren bitamina batzuen xurgapena eta azido biliarraren birxurgapena eragotzi dezakete. Hartzailearen funtzioa guztiz galdu den HoHF kasuetan azido biliarren bahitzaileak ez dira erabilgarriak izaten (42).

\subsection{Beste tratamendu batzuk}

Azken aldian lipoproteinen ekoizpenean eragiten duten hainbat farmako agertu dira. Lomitapide MTP (ingelesez Microsomal triglyceride transfer protein) inhibitzaileak APOB100 apolipoproteinaren lipidazio ezegokia eragiten du hepatozitoetan, VLDL lipoproteinen jariapena ekidinez. Mipomersen, berriz, APOB100 mRNArekin batzen diren oligonukleotidoz osatuta dago eta horiek gibeleko LDL eta VLDL sorrera murrizten dute. Aipatutako bi farmakoek hainbat albo-kalte eragiten dituzte eta HoHF edo arrisku kardiobaskular handiko kasuetan bakarrik gomendatzen dira (43).

HFaren tratamendurako fase klinikoan dauden farmakoen artean evinacumabek, 3. motako angiopoietina (ANGPTL3) inhibitzaileak, emaitza nabarmenak lortu ditu. ANGPTL3 proteinak LDL-C, triglizerido eta $\mathrm{HDL}$ mailak emendatzen ditu LDLR bidezidorrean inolako eraginik izan gabe. Hori delaeta, fase klinikoa gaindituz gero, oso farmako eraginkorra izatea espero da bereziki HoHF pazienteen tratamendurako (44).

Lipoproteina aferesia-arrisku kardiobaskular oso handia duten gaixoengan, hau da, beste terapia guztiek kale egiten dutenean erabiltzen den tresna terapeutikoa da. Estatinek edo PCSK9aren aurkako antigorputzek oso eragin txikia duten gaixoetan edo LDLRaren adierazpenik ez duten HoHF gaixoetan, adibidez, erabiltzen den hurbilketa terapeutikoa da. CVDaren arrisku handia eta iragarpena txarra denean, terapia hori erabili daiteke; kostu ekonomiko handia dakarrenez eta tratamendua luzea eta irisgarritasun txikikoa denez, lipoproteinen aferesia beste teknika guztiak erabilgarriak ez direnean bakarrik gomendatzen da (45).

Orain arte estatinak izan dira kolesterola murrizteko erabilitako tratamendu nagusia, beraien eraginkortasuna eta prezio txikia dela-eta. Beste farmako guztiak estatinekiko errefusa agertzen denean edo haiekin hobekuntzarik ez dagoenean bakarrik erabiltzen dira. Estatinek eragin txikia badute, normalean ezetimibe, PCSK9aren inhibitzaileak edo biak gehitzen zaizkio tratamenduari, emaitza nabarmenak lortuz. MTPaen inhibitzaileak edo ApoB100aren itzulpena inhibitzen duten oligonukleotidoak, tolerantzia txikiko eta kostu ekonomiko handiko teknikak diren arren, LDLRa sintetizatzen ez den HoHF kasuetan LDLaren mailak murrizteko aukerarik erabilienak dira (46). 
Gantz azido jariapenaren inhibitzeileak
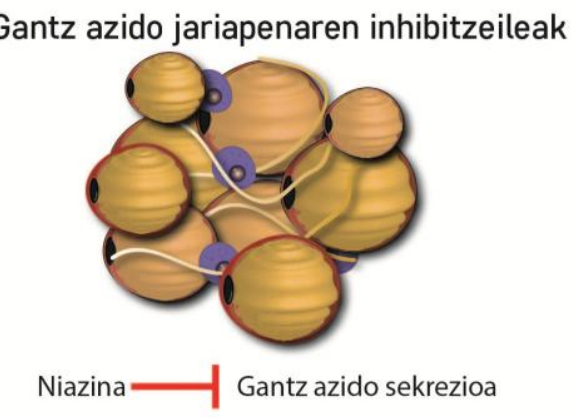

Kolesterol sintesiaren inhibitzaileak

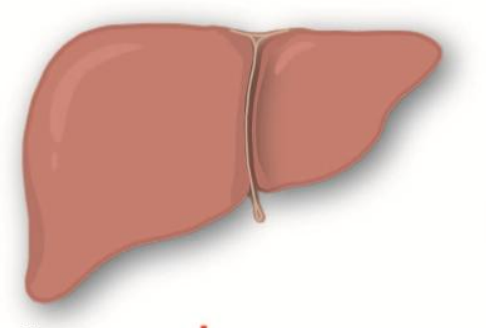

Estatinak - HMG-Koa erreduktasa

Kolesterol xurgapenaren inhibtzaileak
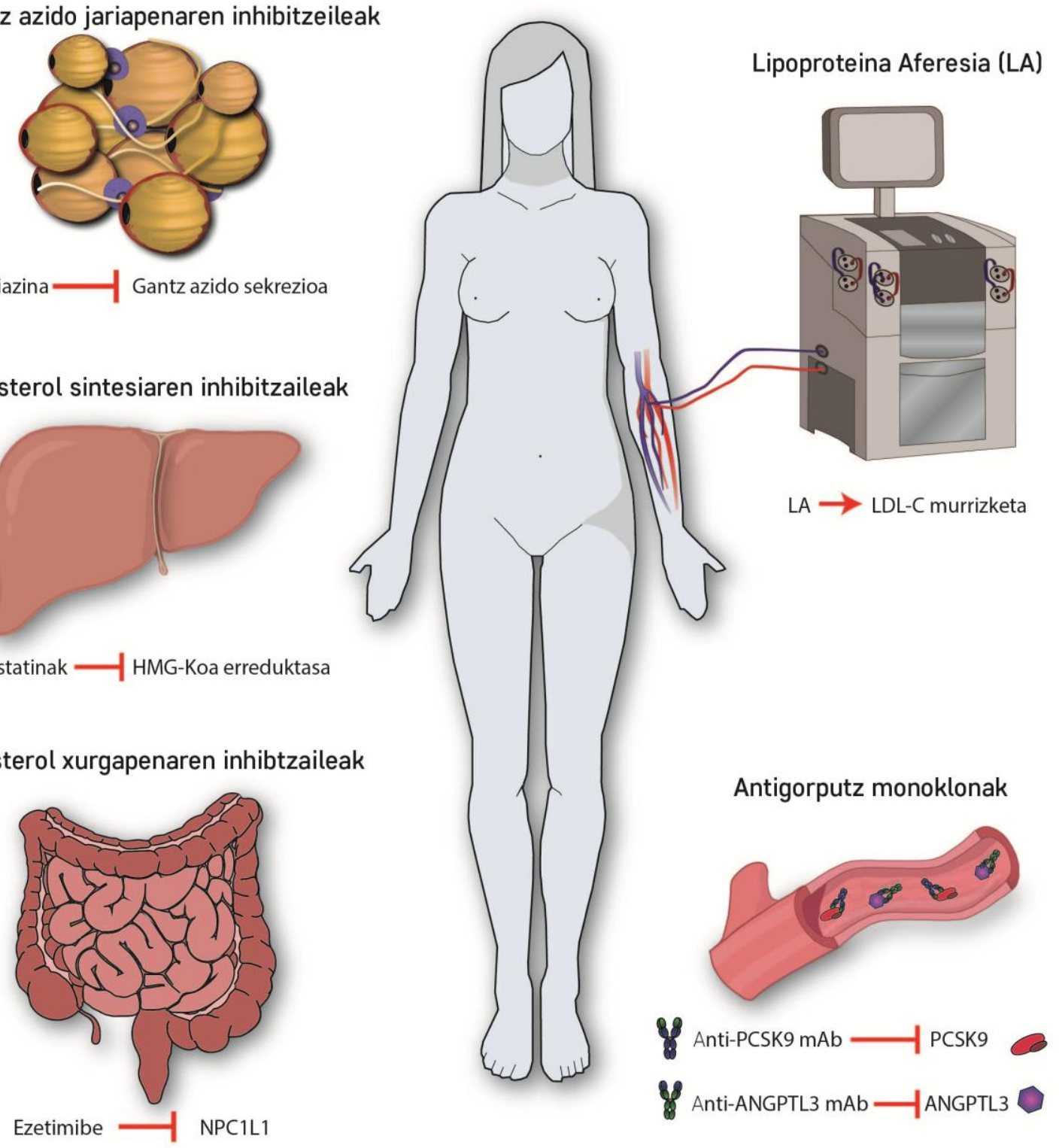

Azido biliarren bahitzaileak

4. irudia. Hiperkolesterolemia familiarraren tratamendurako erabiltzen diren edo erabili diren tratamendu ezberdinak.

\section{Hiperkolesterolemia Familiarra eta nutrazeutikoak}

Nutrazeutikoak onura medikoak eskaintzen dituzten jatorri naturaleko substantziak dira. HFaren tratamenduan erabiltzen diren nutrazeutikoek lipido-maila jaisteko gaitasuna daukate eta, aurretiaz aipatutako tratamenduekin batera, dislipemiak kontrolpean mantentzeko oso erabiliak dira. Nutrazeutikoek kolesterolaren metabolismoaren pauso ezberdinetan eragin dezakete, eta HFaren tratamendu ezberdinen emaitzak hobetu. Landare-esterolek, adibidez, dietatik datorren kolesterolaren xurgapena murriztu dezakete; berberinak, aldiz, PCSK9aren efektua zati batez inhibitu dezake eta arrozaren legamian aurkitzen diren monokolinek, estatinen antzera, kolesterol endogenoaren sintesian eragiten dute (47). 


\section{Hiperkolesterolemia Familiarraren gaurko egoera}

Denboran zehar mantendutako plasmako kolesterol-maila handiek aterosklerosi-plakaren garapena dakarte. Horren ondorioz, tratatu gabeko HFak CVDa izateko arriskua haditzen du (48). Gaur-gaurkoz, kolesterol-maila egonkor mantentzeko zenbait terapia daude. Haien eraginkortasuna, ordea, askoz handiagoa da gaixotasuna goiz diagnostikatzen bada (49). Diagnosi goiztiarra garrantzitsua den arren, gaurkoo diagnosi-tasa oso txikia da. Herrialde gehienetan, HFa duten pertsona gutxik dute diagnosia, $\% 1$ ek baino gutxiagok. Esaterako, Herbehereetan soilik gaixoen \%50 dago diagnostikatuta. Espainian, berriz, gaixo talde horren $\% 6$ inguru diagnostikatu da. Diagnosi-maila eta gaixotasunak daukan prebalentzia kontuan hartuta, munduan HFaren diagnostiko zehatzik ez duten 24-36 milioi pertsona inguru daude, 2013. urteko datuen arabera (4).

Aspalditik, HeHFa hainbat ezaugarri kontuan hartuta diagnostikatu izan da: LDL-Cren maila, HFaren sintoma fisikoak eta pazientearen eta bere familiaren historia klinikoa, esaterako. Diagnosi mota horrek, ordea, HFaren kasu nabarmenenak soilik detektatzeko balio du, tarteko fenotiporik hauteman gabe (50). Gaur-gaurkoz, next generation sequencing tekniken garapenak tarteko fenotipo horien detekzio arina eta erraza ahalbidetu du. Horrek gaixotasunaren genetikan sakontzeko aukera eman du eta diagnosi klinikoarekin batera HF kasu berri ugari agerian utzi ditu.

\section{Erreferentzia bibliografikoak}

1. Brown M, Goldstein J. A receptor-mediated pathway for cholesterol homeostasis. Science (80) . 1986 Apr 4;232(4746):34-47.

2. Ference BA, Ginsberg HN, Graham I, Ray KK, Packard CJ, Bruckert E, et al. Low-density lipoproteins cause atherosclerotic cardiovascular disease. 1. Evidence from genetic, epidemiologic, and clinical studies. A consensus statement fromthe European Atherosclerosis Society Consensus Panel. Eur Heart J. 2017;38(32):2459-72.

3. Vallejo-Vaz AJ, Akram A, Kondapally Seshasai SR, Cole D, Watts GF, Hovingh GK, et al. Pooling and expanding registries of familial hypercholesterolaemia to assess gaps in care and improve disease management and outcomes: Rationale and design of the global EAS Familial Hypercholesterolaemia Studies Collaboration. Atheroscler Suppl. 2016;22:1-32.

4. Nordestgaard BG, Chapman MJ, Humphries SE, Ginsberg HN, Masana L, Descamps OS, et al. Familial hypercholesterolaemia is underdiagnosed and undertreated in the general population: Guidance for clinicians to prevent coronary heart disease. Eur Heart J. 2013;34(45):3478-90.

5. Cenarro A, Etxebarria A, De Castro-Orós I, Stef M, Bea AM, Palacios L, et al. The p.Leu167del mutation in APOE gene causes autosomal dominant hypercholesterolemia by downregulation of LDL receptor expression in hepatocytes. J Clin Endocrinol Metab. 2016;101(5):2113-21.

6. Rios J, Stein E, Shendure J, Hobbs HH, Cohen JC. Identification by whole-genome resequencing of gene defect responsible for severe hypercholesterolemia. Hum Mol Genet . 2010 Nov 15;19(22):4313-8.

7. Etxebarria A, Palacios L, Stef $M$, Tejedor D, Uribe $K B$, Oleaga A, et al. Functional characterization of splicing and ligand-binding domain variants in the LDL receptor. Hum Mutat. 2012;33(1):232-43.

8. Etxebarria A, Benito-Vicente A, Palacios L, Stef M, Cenarro A, Civeira F, et al. Functional characterization and classification of frequent low-density lipoprotein receptor variants. Hum Mutat. 2015;36(1):129-41.

9. Alves, A.C., Benito-Vicente, A., Medeiros, A.M., Reeves, K., Martin, C., Bourbon M. Further evidence of novel APOB mutations as a cause of familial hypercholesterolaemia. Atherosclerosis. 2018;

10. Fernández-Higuero JA, Etxebarria A, Benito-Vicente A, Alves AC, Arrondo JLR, Ostolaza H, et al. 
Structural analysis of APOB variants, p.(Arg3527Gln), p.(Arg1164Thr) and p.(Gln4494del), causing Familial Hypercholesterolaemia provides novel insights into variant pathogenicity. Sci Rep . 2015;5(June):1-8.

11. Abifadel $M$, Varret $M$, Rabès JP, Allard $D$, Ouguerram $K$, Devillers $M$, et al. Mutations in PCSK9 cause autosomal dominant hypercholesterolemia. Nat Genet. 2003;34(2):154-6.

12. Dron JS, Hegele RA. Complexity of mechanisms among human proprotein convertase subtilisin-kexin type 9 variants. Curr Opin Lipidol. 2017;28(2):161-9.

13. Di Taranto MD, Benito-Vicente A, Giacobbe C, Uribe KB, Rubba P, Etxebarria A, et al. Identification and in vitro characterization of two new PCSK9 Gain of Function variants found in patients with Familial Hypercholesterolemia. Sci Rep. 2017;7(1):1-9.

14. Mousavi SA, Berge KE, Leren TP. The unique role of proprotein convertase subtilisin/kexin 9 in cholesterol homeostasis. J Intern Med. 2009;266(6):507-19.

15. Quagliarini F, Vallvé J-C, Campagna F, Alvaro A, Fuentes-Jimenez FJ, Sirinian MI, et al. Autosomal recessive hypercholesterolemia in Spanish kindred due to a large deletion in the ARH gene. Mol Genet Metab . 2007 Nov;92(3):243-8.

16. Wang W, Jiang L, Chen PP, Wu Y, Su PY, Wang LY. A case of sitosterolemia misdiagnosed as familial hypercholesterolemia: A 4-year follow-up. J Clin Lipidol . 2018;12(1):236-9.

17. Muso E. Beneficial effect of LDL-apheresis in refractory nephrotic syndrome. Vol. 18, Clinical and Experimental Nephrology. 2014. p. 286-90.

18. Chrostek L, Supronowicz L, Panasiuk A, Cylwik B, Gruszewska E, Flisiak R. The effect of the severity of liver cirrhosis on the level of lipids and lipoproteins. Clin Exp Med . 2014 Nov 12;14(4):417-21.

19. Nemes K, Åberg F, Gylling H, Isoniemi H. Cholesterol metabolism in cholestatic liver disease and liver transplantation: From molecular mechanisms to clinical implications. World J Hepatol. 2016;8(22):924. 20. Mozaffarian D, Benjamin EJ, Go AS, Arnett DK, Blaha MJ, Cushman M, et al. Heart disease and stroke statistics-2015 update: A report from the American Heart Association. Vol. 131, Circulation. 2015. 29-39 p.

21. Schwenke DC, Carew TE. Initiation of atherosclerotic lesions in cholesterol-fed rabbits. II. Selective retention of LDL vs. selective increases in LDL permeability in susceptible sites of arteries. Arteriosclerosis. 1989;9(6):908-18. 22. Davies PF. Flow-mediated endothelial mechanotransduction. Physiol Rev . 1995 Jul;75(3):519-60.

23. Galkina E, Ley K. Vascular adhesion molecules in atherosclerosis. Arterioscler Thromb Vasc Biol. 2007;27(11):2292-301.

24. Moore KJ, Freeman MW. Scavenger receptors in atherosclerosis: Beyond lipid uptake. Arterioscler Thromb Vasc Biol. 2006;26(8):1702-11.

25. Bench TJ, Jeremias A, Brown DL. Matrix metalloproteinase inhibition with tetracyclines for the treatment of coronary artery disease. Pharmacol Res . 2011 Dec;64(6):561-6.

26. Scientific Steering Committe on behalf of the Simon Broome Register Group. Risk of fatal coronary heart disease in familial hypercholesterolaemia. BMJ. 1991;303(October):893-6.

27. Benito-Vicente A, Alves AC, Etxebarria A, Medeiros AM, Martin C, Bourbon M. The importance of an integrated analysis of clinical, molecular, and functional data for the genetic diagnosis of familial hypercholesterolemia. Genet Med. 2015;17(12):980-8.

28. Etxebarria A, Benito-Vicente A, Alves AC, Ostolaza H, Bourbon M, Martin C. Advantages and versatility of fluorescence-based methodology to characterize the functionality of LDLR and class mutation assignment. PLoS One. 2014;9(11).

29. Benito-Vicente A, Uribe K, Jebari S, Galicia-Garcia U, Ostolaza H, Martin C. Validation of LDLr Activity as a Tool to Improve Genetic Diagnosis of Familial Hypercholesterolemia: A Retrospective on Functional Characterization of LDLr Variants. Int J Mol Sci . 2018 Jun 5;19(6):1676.

30. Sharifi $M$, Futema $M$, Nair D, Humphries SE. Polygenic Hypercholesterolemia and Cardiovascular Disease Risk. Curr Cardiol Rep . 2019 Jun 22;21(6):43. A31. Koopal C, Marais AD, Visseren FL. Familial dysbetalipoproteinemia. Curr Opin Endocrinol Diabetes Obes 
. 2017 Apr;24(2):133-9.

32. Ito MK, Watts GF. Challenges in the Diagnosis and Treatment of Homozygous Familial Hypercholesterolemia. Drugs. 2015;75(15):1715-24.

33. ENDO A. A historical perspective on the discovery of statins. Proc Japan Acad Ser B . 2010;86(5):484-93.

34. Marais AD, Raal FJ, Stein EA, Rader DJ, Blasetto J, Palmer M, et al. A dose-titration and comparative study of rosuvastatin and atorvastatin in patients with homozygous familial hypercholesterolaemia. Atherosclerosis. 2008;197(1):400-6.

35. Schachter $M$. Chemical, pharmacokinetic and pharmacodynamic properties of statins: an update. Fundam Clin Pharmacol . 2005 Feb;19(1):117-25. 36. Sattar N, Preiss D, Murray HM. Statins and risk of incident diabetes: A collaborative meta-analysis of randomised statin trials. Rev Port Cardiol. 2010;29(6):1077-8.

37. Altmann SW. Niemann-Pick C1 Like 1 Protein Is Critical for Intestinal Cholesterol Absorption. Science (80- ) . 2004 Feb 20;303(5661):1201-4. 38. Rosenson RS, Hegele RA, Fazio S, Cannon CP. The Evolving Future of PCSK9 Inhibitors. J Am Coll Cardiol . 2018;72(3):314-29. 39. Gille A, Bodor ET, Ahmed K, Offermanns S. Nicotinic Acid: Pharmacological Effects and Mechanisms of Action. Annu Rev Pharmacol Toxicol . 2008;48(1):79-106.

40. Ross S, D'Mello M, Anand SS, Eikelboom J, Stewart AFR, Samani NJ, et al. Effect of Bile Acid Sequestrants on the Risk of Cardiovascular Events. Circ Cardiovasc Genet . 2015 Aug;8(4):61827.

41. Staels B, Fonseca VA. Bile Acids and Metabolic Regulation: Mechanisms and clinical responses to bile acid sequestration. Diabetes Care. 2009 Nov 1;32(suppl_2):S237-45.

42. Scaldaferri F, Pizzoferrato M, Ponziani FR, Gasbarrini G, Gasbarrini A. Use and indications of cholestyramine and bile acid sequestrants. Intern Emerg Med. 2013;8(3):205-10.

43. Polychronopoulos G, Tziomalos K. Novel treatment options for the management of heterozygous familial hypercholesterolemia. Expert Rev Clin Pharmacol . 2017 Dec 2;10(12):1375-81.

44. Banerjee $\mathrm{P}$, Chan K-C, Tarabocchia M, Benito-Vicente A, Alves AC, Uribe KB, et al. Functional Analysis of LDLR (Low-Density Lipoprotein Receptor) Variants in Patient Lymphocytes to Assess the Effect of Evinacumab in Homozygous Familial Hypercholesterolemia Patients With a Spectrum of LDLR Activity. Arterioscler Thromb Vasc Biol . 2019 Nov;39(11):2248-60. 45. Julius U. History of lipidology and lipoprotein apheresis. Atheroscler Suppl . 2017;30:1-8. 46. Catapano AL, Chairperson EAS, Esc R, Ireland IG, France MJC, Uk PD, et al. ESC / EAS Guidelines for the management of dyslipidaemias The Task Force for the management of dyslipidaemias of the European Society of Cardiology ( ESC ) and the European Atherosclerosis Society ( EAS ) $ם, \leftleftarrows \square$ 2011;217:3-46.

47. Gylling H, Plat J, Turley S, Ginsberg HN, Ellegård L, Jessup W, et al. Plant sterols and plant stanols in the management of dyslipidaemia and prevention of cardiovascular disease qq. 2014;232:346-60.

48. Mortality in treated heterozygous familial hypercholesterolaemia: implications for clinical management. Scientific Steering Committee on behalf of the Simon Broome Register Group. Atherosclerosis . 1999 Jan;142(1):105-12. 49. Palacios L, Grandoso L, Cuevas N, OlanoMartín E, Martinez A, Tejedor D, et al. Molecular characterization of familial hypercholesterolemia in Spain. Atherosclerosis . 2012 Mar;221(1):137-42. 3

50. Civeira F, Ros E, Jarauta E, Plana N, Zambon D, Puzo J, et al. Comparison of Genetic Versus Clinical Diagnosis in Familial Hypercholesterolemia. Am J Cardiol. 2008;102(9). 